\title{
Representing environment and development - tracing links between drivers, representations and power dynamics in cocoa sustainability and beyond
}

\author{
Judith Krauss ${ }^{1}$ \\ University of Manchester, UK
}

\begin{abstract}
How much do misleading representations matter? This article examines carefully constructed narratives of engagement in 'sustainable' cocoa production initiatives, which fail to mention one of the actual key drivers: the need to shore up production in the long term in an embattled sector. Consequently, representations also downplay the need for systemic change, reproducing the power asymmetries they claim to change. The research seeks to establish to what degree public-facing communication differs from underlying priorities in terms of forefronting altruism over necessity, and whether this is problematic for the initiatives' overall outcome. Through semi-structured interviews, focus-group discussions, documentary analysis and participant observation in Latin America and Europe, it reviews relations in two cocoa sustainability initiatives with environmental foci. Crucially, the research establishes a link between representations, underlying priorities and the degree to which they (re)produce pre-existing power asymmetries between global North and global South, private sector and other stakeholders in the industry, speaking to a variety of political ecology questions. It argues that public-facing, altruism-focused communication distracts from the sector's underlying systemic issues: the emphasis on altruism works to reduce pressure to transform power asymmetries and omnipresent inequalities.
\end{abstract}

Keywords: Representations; cocoa; sustainability; ethical consumption; environment; global South; development; political ecology

\section{Résumé}

Quelle est l'importance des représentations trompeuses? Cet article examine des récits soigneusement construits sur l'engagement dans des initiatives de production de cacao «durables», qui ne mentionnent pas l'un des principaux moteurs: la nécessité de renforcer la production à long terme dans un secteur en difficulté. Par conséquent, les représentations minimisent également la nécessité d'un changement systémique, reproduisant les asymétries de pouvoir qu'elles prétendent changer. La recherche cherche à déterminer dans quelle mesure les communications publiques se distinguent des priorités sous-jacentes en termes de prévention de l'altruisme par rapport à la nécessité et si cela est problématique pour le résultat global des initiatives. A travers des interviews sémi-structurées, discussions dans de groupes focus, analyse des documents and observation en Amérique Latine et Europe, cet article revoit relations dans deux initiatives pour la durabilité du cacao avec des mesures environnementales. Fondamentalement, la recherche établit un lien entre les représentations, les priorités sous-jacentes et la mesure dans laquelle elles (re) produisent des asymétries de pouvoir préexistantes entre le Nord et le Sud mondial, le secteur privé et d'autres parties prenantes du secteur. L'article aborde diverses questions d'écologie politique. Il soutient que la communication publique orientée vers l'altruisme détourne l'attention des problèmes systémiques sous-

\footnotetext{
${ }^{1}$ Dr. Judith E. Krauss, Lecturer, Global Development Institute, University of Manchester, UK. Email: judith.krauss "at" manchester.ac.uk. Thank you very much to everyone who made a contribution to my research in whatever way - your time, expertise and kindness are much appreciated! I acknowledge gratefully funding through the Sustainable Consumption Institute and ESRC grant ES/J500094/1. Thank you very much to the Politics and the Environment Research Group at Manchester, Phil Woodhouse, Dan Brockington and one anonymous reviewer for helpful comments - all errors remain mine. I declare no potential conflicts of interest with respect to the research, authorship, and/or publication of this article.
} 
jacents du secteur: l'accent mis sur l'altruisme contribue à réduire la pression pour transformer les asymétries de pouvoir et les inégalités omniprésentes.

Mots-clés: Représentations; cacao; durabilité; consommation éthique; environnement; le Sud mondial; développement; écologie politique

\section{Resumen}

Cuál importancia tienen representaciones engañosas? Este artículo examina narrativas construidas con mucha atención sugiriendo compromiso en iniciativas cacaoteras "sostenibles', las que no mencionan una prioridad esencial subyacente: la necesidad de mantener producción al largo plazo en un sector en crisis. Como consecuencia, las representaciones minimizan en comunicación la importancia de un cambio sistémico y reproducen las asimetrías de poder que pretenden corregir. La investigación desea establecer a cual grado la comunicación dirigida al público se varían de las prioridades subyacentes en cuanto a destacar altruismo en vez de necesidad, y si esta dinámica es problemática para los resultados de la iniciativas. A través de entrevistas semi-estructurados, discusiones en grupos focales, análisis de documentos y observación participativa en América Latina y Europa, el artículo analiza dos iniciativas de sostenibilidad cacaotera con un enfoque ambiental. Esencialmente, la investigación establece un vínculo entre representaciones, prioridades subyacentes y la (re)producción de asimetrías de poder entre Norte y Sur global, entre sector privado y otros actores en el sector, lo que tiene relevancia para una variedad de preguntas de ecología política. Su argumento es que una comunicación pública que se enfoque sobre altruismo distrae de los problemas sistémicos en el sector: el enfase en filantropía reduce la presión para una transformación de asimetrías de poder y desigualdades omnipresentes.

Palabras claves: Representaciones, cacao, sostenibilidad, consumo ético, medio ambiente, Sur global, desarrollo, ecología política

\section{Introduction}

How much do misleading representations about sustainability matter? Given the omnipresence of communication and sustainability, there are few actions in any way related to corporate, social or environmental responsibility which public-sector, private-sector and civil-society stakeholders will not advertise as 'sustainable' (Adams 2009). However, stakeholders' underlying interpretations of the priorities that should govern sustainability diverge considerably, meaning that the term's polysemic nature entails tensions in practice. Public representations of congruence or commensurability between diverse interpretations of what sustainability is or should be entail considerable risks, explaining the need to analyze mediated narrative filters (Alexander 2018). This article posits that public representations of harmony between different stakeholders' understandings of 'sustainability' distract from and even perpetuate underlying inequalities and power asymmetries between global North and South, which matters given actors' resulting unequal ability to influence decision-making (Elgert 2012). Indeed, the meanings which powerful stakeholders deploy (Hall 1997a,b) can work to undermine the goals of partnership that such initiatives purportedly pursue.

The context is the cocoa sector and the surging interest in 'sustainability' since 2010 (Barrientos 2014; Tampe 2016). In a sector encompassing a concentrated marketplace of large-scale private-sector stakeholders from the global North and a very fragmented landscape of five million cocoa producers, there are considerable power differentials at play, which merit unpacking. At the same time, socio-environmental and commercial issues caused in part by these persistent power inequalities are exacerbating concerns about projected cocoa shortages. The diversity of cocoa actors from the public sector, private sector and civil society contribute a considerable spectrum of what socio-economic, commercial and environmental issues are considered paramount to attain 'sustainability.' Amid this fluidity of underlying priorities (Raynolds 2009), actors' public-facing representations about sustainability shape perceptions of buyer-producer relations. There is growing public interest in the socio-environmental circumstances of production, and the degree to which consumption condones the policies, market forces and inequality which are tied to their negative dimensions (Hoelle 2017). Consequently, an analysis of both drivers and representations of sustainability offers insights in terms of the power dynamics allowing some actors, but not others, to project 
both their representations and their priorities onto initiatives. This article presents two case studies not previously investigated in the literature to address a research gap on the environmental side of cocoa sustainability, and illustrates broader sector dynamics. It draws on in-depth fieldwork in Latin America and Europe to make a unique contribution in terms of questioning flawed assumptions about sustainability initiatives inherently equalizing power and philanthropically 'helping' producers. In emphasizing how public-facing representations reproduce the power asymmetries that initiatives claim to eliminate, it contributes to a broad range of political ecology exchanges surrounding questions of:

- What links production and consumption contexts?

- Who can make what decisions?

- Who benefits?

While it is based on research in the cocoa sector, it raises questions that resonate strongly with much broader debates in the nexus of development studies, political ecology and consumption studies into sustainability and sustainability narratives.

The article's argument is that the meanings which powerful stakeholders deploy in representations of cocoa sustainability initiatives partly undermine the goals they purportedly pursue. Representations forefront notions of altruism and partnership with local producers and depict slightly tweaked business-asusual to be the right approach, none of which is particularly surprising. The key contribution, however, is to raise questions about what this means in practice for production and consumption, as these manifestations crucially reduce the likelihood of the sector implementing the transformative changes necessary to address systemic issues caused in part by power asymmetries and Northern-dominated priorities. Representations forefronting altruism thus reduce pressure to transform power asymmetries and omnipresent inequities, which raises vital questions about sustainability assumptions and dynamics far beyond the cocoa sector.

To substantiate this argument, this article analyzes stakeholders' public-facing representations in two cocoa sustainability initiatives, and questions how these instances of communication relate to underlying priorities and power dynamics. It will firstly discuss what representations are in the context of sustainability and ethical consumption, emphasizing their crucial role in imagining development and projecting power. After a brief review of the cocoa sector's intensifying pressures, the manuscript analyzes two cocoa sustainability initiatives bringing together commercial, socio-economic and environmental elements to review tensions in terms of public-facing representations, underlying priorities and stakeholder relations. It will end by thinking through the implications of these findings for representing environment and development beyond the cocoa sector.

\section{Methodology}

The study draws on in-depth fieldwork in Latin America and Europe conducted in the cocoa sector between 2013 and 2017. The author consulted 96 key informants from the private sector, public sector and civil society through semi-structured interviews, held three focus group discussions with responsive consumers as well as nine public engagement sessions, conducted participant observation at nine cocoarelated sessions and analyzed over 400 documents. To comply with ethical approval, pseudonyms have been used for all stakeholders. Selecting cocoa global production networks (Henderson et al. 2002; Hess 2004) which prioritize environmental matters given these initiatives' underrepresentation in the literature, the study aimed to analyzes these networks holistically. Incorporating voices from cocoa producers and cooperatives via non-governmental organizations and chocolate companies to responsive consumers exemplifies a breadth and depth of empirical engagement that few studies attain. The objective in selecting four different methods was drawing on data from diverse sources cognizant of their provenance and intended audience (Barrientos 2002; Laws 2003; O'Laughlin 2007), aiming to establish the priorities governing stakeholder engagement, the representations used in public-facing communication, and underlying power relations to engage with broader debates on sustainability. 


\section{Consuming representations: constructing producer-consumer relations}

To substantiate my argument that representations deployed through cocoa sustainability initiatives partly reduce pressure to transform inequalities, a discussion of what representations are and how they relate to sustainability drivers and power dynamics is necessary. Bryant and Goodman, in their political ecology analysis of consumption narratives and behaviors, have convincingly argued that consumption in the global North increasingly is portrayed as the new activism, with purchase choices represented as a way to make a difference and express ethical convictions (2004: 344). Communicating these ideas is predicated on representations, i.e. "the signs and symbols ... [which] stand for or represent to other people our concepts, ideas and feelings" (Hall 1997a: 1). This study aims to analyze representations in terms of the "production of meaning through language", i.e. how stakeholders "use signs to communicate meaningfully with others" (Hall 1997b: 28). Representative forms and language mediate all learning about our world (Benjamin 1989; Lewis et al. 2008): representation simultaneously constitutes a conduit and filter between private sector, civil society, public sector and the public-at-large, including consumers, in re-presenting, i.e. presenting again (O'Shaughnessy and Stadler 2005), what sustainability initiatives are and will entail.

Consuming a product is concomitant with consuming its meaning as expressed through public-facing communication and advertising, notwithstanding all the cognitive dissonances that these associations yield (Baudrillard 1976, 1988, 1998, 2001). Purchases come with ubiquitous manifestations of spectacle, i.e. commodified images conveying connotations and thereby mediating social relations (Debord 1967). The power inherent in this construction of consumer-producer relations becomes evident in Büscher's observation about derivative value: value can be based not on what is, but what should be according to those projecting their own meanings onto nature and communities (2010). As always, the question is what nature, and what ideas of community in this instances, are being commodified (Castree 2003)? From a political ecology perspective, who can project what meanings is crucial, and instructive in terms of underlying power relations and of deciding representations. Bryant and Goodman (2004) argue that fair trade products have both narrative and material production moments, meaning that products create and placate consumer expectations (Hilson 2014) and can acquire a dimension of a 'moral economy' (Goodman 2004). The 'difference-making' discourse takes on material form as part of the 'ethical' or 'sustainable' items purchased. Certifiers assume a role as 'stewards of virtue' for products bearing their seals (Blowfield and Dolan 2008). They support philanthropy or charity by way of consumption choices (Wilkinson 2007). The media of communication thus serve as a transformative agent: it represents reality in a certain way, rather than mirroring it (Lewis et al. 2014b: 4).

Consequently, those who have the capability to shape representations by directing initiatives' communication as well as audience responses, to a degree, project considerable power. Lukes's understanding of power crucially emphasizes that exerting power need not be explicit, occurring through unconscious mechanisms (2005). His three-dimensional understanding of power also makes the vital point that the powerless may act seemingly in contravention to their own interests, in response to pervasive systems of perceptions built through 'power as domination.' Representations are thus an excellent example of a latent projection of power, since power, with Max Weber, is having at one's disposal the means to instigate desired behaviors or perceptions (2005[1922]). These will sometimes be rooted in economic relations: those at the receiving end of public-facing communication will often be unaware of the framing choices that have gone into representations communicated by (economically) dominant actors. Conversely, given these filters, narratives deployed as neutral and consensus-based may eventually prove contested, such as 'sustainability' or 'the environment' (Caplan 2016), if and when conflicting representations or ideas emerge. Analyzing narratives can thus reveal differing perceptions of sustainability problems and solutions between and among different groups and provide insight into underlying power asymmetries and tensions, benefiting from and contributing to a variety of political ecology angles (Bixler 2013).

In development contexts, representations acquire even greater importance given the distance between producers and consumers in terms of geography and life-reality (Lewis et al. 2013). Silverstone's notion of 'proper distance' is interesting to consider here (2007). Creating relationships across the North- 
South divide linking consumers and producers was an innovation of the fair trade movement (Raynolds 2002: 404), with stakeholders often deploying narrative testimonies to underline how representations bridge asymmetries (Bryant and Goodman 2004: 357). Silverstone emphasizes that media are a crucial conduit determining senses of responsibility between the subjects and audiences of representations: "We need to be close but not too close, distant but not too distant" (2007: 172). The products consumed, and those producing them, are commodified through the narratives of those deploying representations (Carrier 2010). What is more, very often an aspect implicit or explicit in representations is how stakeholders construct a need for outside assistance (Crush 1995: 10), i.e. a narrative of communities in need of 'help.' The very notion of help and charity a priori suggests lop-sided power relations between stakeholders. Representations depicting fair prices as acts of charity neglect that logically, charity cannot apply if there is reciprocity in the shape of a commodity changing hands. Constructing a narrative of 'helping' aims to galvanize philanthropic support rather than create equitable relationships in which all sides benefit. Indeed, as long as constructions of solidarity are predicated on powerless people of color in the global South needing help, they perpetuate the power asymmetries and inequalities that narratives of 'partnership' purport to bridge: style trumps substance, and alters it. Below, I address to what extent 'helping' and 'partnership' assume a prescriptive normativity, predetermining the conduct that Northern consumers will support while limiting the degree to which Southern communities can influence decision-making.

Similarly, the possibility of assisting 'nature' through one's wallet embodies an alleged connection with nature as a place and also as a style of living (Bryant and Goodman 2004: 354). Paradoxically, the very act of buying a plethora of 'nature'-related products contravenes the non-consumptive lifestyle associated with 'nature', constituting a failure to challenge the Northern cognitive dissonance of continuing degrading practices while supporting worthwhile causes far away (McAfee 1999). There is a strong link firstly to John Muir's idea of a "wilderness ethic as an escape from the evils of modern civilization" (Kalamandeen and Gillson 2007: 167): a key question, however, is what wilderness or nature the image is proposing to return to (Cronon 1996). Secondly, Carrier asked whether capitalist markets contradict the very values they suggest consumers can attain by way of "ethical consumption" (2010: 675-680). After all, some manifestations that set out to be 'alternative' consumption models have since become enveloped by conventional food systems, thereby boosting the mainstream distribution channels in opposition to their original goals (Goodman et al. 2010: 1783). Capitalist markets' abiding, and accelerating, destructive effects on nature and society cause some to call 'ethical' consumption an oxymoron as long as it does not challenge the fundamental underlying inequalities disadvantaging the global South and nature (Soper 1998). This tension also underlies Goodman's call to develop 'alternatives to the alternatives' (2010), as it questions the degree to which initiatives redress, claim to remedy or reproduce power asymmetries in terms of representations projected, drivers enacted and benefits attained. The next section will contextualize initiatives in the cocoa sector before exploring the two case studies in terms of representations, priorities and underlying power dynamics.

\section{Cocoa sustainability initiatives and the environment: changing drivers, altruistic representations, same power dynamics?}

A study of sustainability representations and their links to underlying priorities and power dynamics is particularly interesting in the cocoa sector, given this industry's plethora of sustainability initiatives in answer to a perceived crisis. Securing supply in accordance with stakeholders' quality requirements is an increasingly relevant priority in cocoa-chocolate (Barrientos 2014). Given experts' projections in the early 2010s expecting demand to exceed 2009/10 levels by 25\% by 2020, some began to doubt how cocoa production could meet demand and quality requirements (Hütz-Adams and Fountain 2012; Thornton 2010). These projected shortages caught the sector's attention, prompting key players to begin engaging with notions of sustainability which had been the domain of small-scale, $100 \%$ ethical chocolate manufacturers for decades (Barrientos 2014; Tampe 2016).

Diverse factors have combined to trigger concerns as to whether quality and quantity of cocoa supply can match long-term demand. In environmental terms, conventional practices and productivity-maximizing 
pressures are degrading the limited extent of suitable soils in tropical zones, with climate change impacts adding further uncertainty (CIAT 2011; Ofori-Boateng and Insah 2014). Among the socio-economic factors causing concern, a key problem has been that net returns for cocoa growers have been dwindling for decades (Barrientos et al. 2008; Fountain and Hütz-Adams 2015; Hainmueller, Hiscox and Tampe 2011; Hütz-Adams and Fountain 2012), requiring a marked improvement in economic viability to motivate younger generations (Nieburg 2017). In commercial terms, especially between global North and South and private-sector actors and other stakeholders, the cocoa sector exhibits substantial power asymmetries. Of late, the structures already concentrated in the cocoa marketplace have shown further signs of contracting (Barrientos 2014; Cargill 2015; Nieburg 2013). This has given rise to concerns about maintaining supply, and acceptable cocoa prices. Considering this nexus of factors, private-sector stakeholders in particular are wondering where their bread-and-butter ingredient - cocoa - in a quality which meets their price, quality and ethical standards is to come from in the medium to long term. Consequently, the engagement with cocoa sustainability is morphing from 'nice-to-have' to a business imperative, although different stakeholders' implementation and understanding of sustainability diverge considerably.

Even though ever more cocoa stakeholders are engaging with 'sustainability', how they frame it and how they aim to attain it differs considerably. Multi-stakeholder initiatives have proved very common (Bitzer et al. 2012), suggesting a broad consensus that no one actor can resolve the sector's crisis alone. Against the backdrop of an ever-increasing interest in labeling through voluntary private standards (Hughes 2001; Zadek 1998), many stakeholders have opted to work with independently monitored certification schemes (Fountain and Hütz-Adams 2015; Hütz-Adams and Fountain 2012). However, question marks about the validity and implications of standards are particularly relevant in the cocoa sector's current situation (e.g. Oya et al. 2017). Recurring points of criticism include the question of whether standards may imprint Northern biases and representations, imposing supposedly universal values and monitoring processes (Klooster 2006; Marin-Burgos, Clancy and Lovett 2015; Tharoor 1999). There is therefore an issue as to whether they reflect the priorities of intended beneficiaries in the global South (Henson and Humphrey 2008) as Southern producers' ability to influence the development of standards is variable (Bendell 2005). Beyond the above-mentioned question of tokenistic 'helping' rather than substantive behavioral changes, a broader issue with certification and ethical consumption is a pattern of becoming a 'victim-of-its-own-success': as the clientele is widening towards circles seeking token engagements, commitment to altruistic causes weakens. At the same time, the demand for malleable initiatives with more flexible standards or monitoring requirements rises. While expansion allows more producers market access (Wilkinson and Mascarenhas 2007), this notional success may also entail dilution (Smith 2008). This dynamic recalls a broader issue relating to recurring tensions between the commercial and social objectives of certification standards (Mason and Doherty 2016). In the context of the cocoa sector, it raises the question as to whether sectoral urgency becomes more important than a requirement for unassailable monitoring of socio-environmental improvements. These observations underline the need for a careful analysis of stakeholders' priorities, their ability to influence standard selection and implementation, and the representations they deploy.

This diversity of implementation continues in terms of the multitude of socio-economic, environmental and commercial priorities that stakeholders pursue through their cocoa sustainability initiatives. Beyond the question of whether cocoa sustainability is even feasible, following Redclift's contention that sustainable development is an oxymoronic term (2005), we must question how sustainability's manifold different understandings are relevant here (Adams 2009). Cocoa cultivation offers scope to implement a variety of competing policy demands (Franzen and Borgerhoff Mulder 2007). This diversity of goals ranges from boosting food security, farmer organization and income in the socioeconomic realm, to environmental priorities such as carbon sequestration, biodiversity and forest conservation and organic certification, to safeguarding supply and high quality of cocoa in the commercial realm (Krauss 2017). Depending on every stakeholder's background and motivation, they will prioritize different goals; a constant is that dominant stakeholders are able to imprint their understandings onto sustainability initiatives. As speaking to a diversity of cocoa stakeholders about 'sustainability' demonstrates very palpably, genuine cocoa sustainability is notoriously difficult to define given different stakeholders' 
diverging understandings. Nevertheless, it appears to involve engaging with the drivers prioritized by growers in the global South, i.e. those producing cocoa through hard physical labor. As Southern growers' share in retail revenue from chocolate is miniscule compared with the value added retained by Northern companies and manufacturers (Fountain and Hütz-Adams 2015), genuine sustainability involves redressing this imbalance. More fundamentally, it means moving production from short-termist thinking towards incorporating Southern producers' expert voices to sustain production both socio-economically and environmentally. Given these existing power asymmetries in the cocoa sector, and the limited voice which Southern producers have, it is important to analyze the priorities which dominant stakeholders imprint onto sustainability initiatives, and the way they relate to communicated representations.

The confluence of commercial, socio-economic and environmental factors causing shortage concerns is thus widening the spectrum of private-sector, public-sector and civil-society stakeholders working to improve different aspects of cocoa production (Glin et al. 2015: 44; Matissek et al. 2012). However, there is a question to what extent these sustainability initiatives are addressing, or perpetuating, existing power asymmetries. When analyzing drivers and their relationship to representations, Raynolds' (2009) analysis of fair trade coffee buyers is particularly relevant. She argues that although their behavior may be identical, i.e. buying fair trade rather than conventional coffee, their underlying motivations for doing so matter greatly in determining strategy and outlook. Mission-driven buyers fully subscribe to an altruistic ethos, while qualitydriven buyers mostly seek high-quality supplies. By contrast, market-driven buyers are chiefly motivated by the commercial opportunity that ethically conscious consumers embody. Although these distinctions are to be understood as a continuum rather than distinct categories, they are situated in rather different places on the spectrum in three key ways:

- firstly on the above-mentioned question of tokenistic helping vs. remedying trade inequalities,

- secondly in terms of the reliance on unassailable monitoring,

- and finally whether stakeholders are seeking to remedy, or uphold, existing power asymmetries.

In the context of cocoa sustainability, there is therefore a need to analyze the provenance of stakeholders' diverse underlying motivations, the links between these drivers and public-facing representations, and their connections with power. The question is whether 'sustainability' initiatives are addressing the sector's underlying power asymmetries, or producing and reproducing existing power relations and priorities through dominant actors projecting representations in their favor.

Consequently, the following section will use two cocoa sustainability initiatives with environmental foci as case studies, 'Our Chocolate' and Floral. Building on the above-cited literature, it will analyze representations, this study's chief focus, and stakeholders' underlying priorities. In combination, the lenses of stakeholders' ability to project priorities and impose perceptions in terms of public-facing meanings will help explore the implications of these initiatives for Southern producers and underlying power relations, analyzing to what degree sustainability initiatives address or reproduce existing inequalities.

\section{Case studies: Our Chocolate and Floral}

In order to exemplify public-facing representations in cocoa sustainability initiatives and their links to underlying drivers and power dynamics, I present two case studies with prominent environmental components to support my argument that representations partly contravene the stated purpose of initiatives, and that this dynamic is problematic. These observations lay the groundwork for the analysis of the production and reproduction of meaning through representations, and their broader implications, in the following section. The first case-study, Our Chocolate, is a small-scale partnership between Colombian cocoa communities and several municipalities in Europe, while Floral brings together a medium-sized chocolate company with Nicaraguan cocoa farmers. 
Our Chocolate: dynamics, drivers and representations

'Our Chocolate' brings together two adjacent municipalities in Colombia with municipalities in the global North who have successfully applied for public funds to establish cocoa-cum-climate partnerships with the global South (Climate Alliance 2014a, b; Agenda21 2015). Following a climate change mitigation conference aiming to promote intercontinental partnerships, the Northern municipalities planned to sell Our Chocolate as a 'local' endeavor in the North. The project was to combine a socio-economic livelihood opportunity for farmers with an environmental approach promoting both carbon sequestration and conservation in a territory harboring the largest terrestrial national park in Amazonia:

We want to grow cocoa in agroforestry systems, with fruit trees, which are very important for food security, and timber trees for income. A lot of forest has been destroyed through agriculture - we are aware of that and want to change that, and we also need to find opportunities for our young generation." ${ }^{2}$

The premise unites a Colombian territory with high conservation value with two Northern municipalities aiming to improve their ecological footprint and support a social development venture. In the Colombian municipalities of Tilón and Comuno, seventy farmer families grow cocoa, with the beans then fermented and dried by farmers in a decentralized manner. ${ }^{3}$ As the area's remoteness dictates this decentralized approach, the resulting uniqueness of each sack of cocoa beans requires processing by a small-scale bean-to-bar manufacturer. ${ }^{4}$ The artisanal chocolatier transforms the fine-flavor cocoa into Our Chocolate, sold or given away in tourist information or speciality shops in multiple municipalities. ${ }^{5}$

While both Colombian municipalities contribute $10 \%$ of project funding, the bulk originates from the global North. This significant power differential is confirmed when analyzing project documents written by Northern stakeholders versus those written by Southern representatives. Southern parties' socio-economic aspirations such as renewable energy and electrification are far less prominent in Northern representations of the project than Northern municipalities' interest in chocolate to be sold and carbon to be sequestered (Corporación Tilón 2014; Tilón 20146): this makes power asymmetries in terms of priority-setting and representation-setting evident.

The initiative uses multiple public-facing outlets to communicate its representations, including the chocolate wrapper, multiple websites and public project presentations in Northern municipalities. The chocolate wrapper varies in visual, but not written presentation: different municipalities display either their own town hall or the Amazonian rainforest, thereby using vastly different visual strategies. This resonates not only with Silverstone's idea of proper distance (2007), but is equally relevant in terms of agency behind and beneficiaries of the project, as the analysis will discuss further. The wrapper's written inlay presents the project as follows (Otterbach 2014: 1):

This chocolate helps to support small-scale farming families in Comuno and Tilón who wish to protect their rainforest from deforestation through sustainable agriculture. Agroforestry, as the practice is called, in the rainforest preserves biodiversity of plants and animals and protects the

\footnotetext{
${ }^{2}$ Interview \#138, cocoa producer, 7 July 2014.

${ }^{3}$ Interviews \#143, development representative, 2 September 2014, and \#18, civil society representative, 12 November 2013.

${ }^{4}$ Interview \#135, private-sector representative, 23 June 2014.

${ }^{5}$ Interviews \#18, civil society representative, 12 November 2013; \#19, private sector representative, 12 November 2013; \#44, government representative, 28 November 2013; \#135, private sector representative, 23 June 2014; \#136 and 137, government representatives, both on 26 June 2014.

${ }^{6}$ Also based on interviews conducted: Interviews \#23 and \#44, government representatives, 16 December 2013 and 28 November 2013; Interview \#143, development representative, 2 September 2014.
} 
climate. The small-scale farmers receive a fair price for their commitment and the special quality of their cocoa....

Through climate partnerships ... the small-scale farmers are receiving advice, training and support in further developing this particular rarity: cocoa certified under strict organic standards and traded fairly.

This text formulated by the Northern municipalities is interesting for several reasons. Firstly, it places the agency for wishing to protect 'their' rainforest firmly with Colombian farming families. Secondly, it creates a direct link between consumers purchasing high-quality chocolate and rainforest protection, drawing very narrow lines around what nature is to be returned to and supported (Cronon 1996) and positing that this can be attained through a market mechanism, irrespective of capitalism's destructive forces (Soper 1998). This connection equally recalls McAfee's cognitive dissonance of supporting far-away causes without addressing one's own behavior first (1999), as well as Bryant and Goodman's (2004) political ecology analysis of the powerful associations emerging in relation to rainforest and nature narratives. What is more, this simplified automatism neglects that cocoa trees take several years to yield viable livelihoods.

The tenuous connection made between cocoa purchase and reduced deforestation also omits that the project's small cocoa volumes are unlikely to challenge large-scale and global dynamics such as oil demand and local beneficiaries pushing forward deforestation. This is a scale discrepancy which caused skepticism in focus-group discussions ${ }^{7}$ : "The story of municipalities, it sounds great, but it is completely negligible when it comes to economic effects, and it'll also be the first to die, certainly after one term of office ... It's a nice thought though." ${ }^{8}$ The actual source of funding, project money, is only mentioned in the final paragraph. A third interesting aspect is that the text emphasizes environmental and consumer benefits such as taste over socio-economic benefits to producers: before there is any indication of families receiving a fair price, the rainforest, deforestation, biodiversity and climate are mentioned. There is thus a clear picture in terms of what nature is being commodified (Castree 2003): a nature which produces cocoa in the rainforest. In this Northern-facing communication, communities' focus on electrification and renewable energy is absent and replaced by environmentally-themed benefits, questioning the initial location of agency with Colombian families and exemplifying the actual distribution of decision-making power in favor of the global North.

Similar patterns are observable in online representations. For instance, one municipality introduces the initiative on an Agenda 21 website under the heading "A partnership with tasty fruits - Chocolate as a climate protection measure" (Agenda21 2014), with the key emphasis again being on environmental aspects, and protection of a very specific type of nature. Equally, the text highlights Colombian actors' agency in requesting support from the global North, emphasizing the need for external assistance. Paradoxically, the need for 'helping' limits the choices of those the narrative purports to help, setting boundaries for what conduct is expected of Southern producers to comply with Northern expectations. A direct connection is established between consumers' choice of chocolate, and the importance that consumers attach to rainforest protection, thereby creating the spectacle of a common enemy, i.e. deforestation, which constituencies in South and North are fighting jointly.

The project organized various public engagement measures in which visiting Colombian representatives met the general public and decision makers from Northern municipalities to galvanize support. Interestingly, the question regarding project scale and impact raised by focus groups did not surface in a public project presentation; instead, the project was lauded for building a partnership-based supply chain and promoting trust through mutual and personal visits. The absence of queries on this point casts doubt over how much measurable impacts matter for a small-scale project relying predominantly on local association, and to what degree in-person presentations, visual images and an internet exchange platform

\footnotetext{
${ }^{7}$ Focus group discussions with an environmental group on 5 December 2013, and with staff of a non-food corporation on 29 May 2014.

${ }^{8}$ Focus group discussion on 29 May 2014, Participant 3h.
} 
can create greater societal buy-in than unassailable monitoring. This point is relevant for broader debates around sustainability standards, as explored in more detail below: it suggests that palpable, measurable and monitored improvements for the cocoa growers producing cocoa through physical labor in the global South may not be as essential as plucking at heartstrings successfully by feeding into romanticized notions of 'helping' and relating to nature.

Despite repeated references to 'partnership' in public presentations of the project and in internet communication, there is thus a question to what extent Southern stakeholders are able to contribute priorities and determine this initiative's direction. Firstly, the Southern focus on electrification and renewable energy was not matched by Northern representations prioritizing chocolate and climate benefits, as discussed above. Secondly, at a public project presentation, Colombian stakeholders' statements were being translated from Spanish into German, with project staff adding additional explanation - for instance highlighting the project's remoteness. While intending to build partnership, this strategy also prioritizes a representation of events by German project staff over Southerners' voices, and the lengthened explanations aroused suspicion, even with public engagement attendees who did not speak Spanish. Moreover, they highlighted the need for external assistance (Crush 1995). They also risked portraying "individuals, governments and communities as 'underdeveloped' and treated as such" (Escobar 1995: 123) and perpetuating colonial paternalism towards people of color in the global South. Moreover, a translation being twice as extensive as the Spanish original creates a sense of power being located in the global North in keeping with Weber's idea of projecting perceptions: this finding is in keeping with this article's analysis, but at odds with the above-highlighted representations emphasizing partnership and Colombian agency.

Overall, the foci of how Northern municipalities represent the project are the initiative's environmental and taste benefits for consumers. Emphasizing electrification, a socio-economic priority for Colombian stakeholders, would highlight a provision which Southern producers lack, but Northern consumers take for granted, accentuating unfair Northern privilege. Instead, the environment-centric representations construct a joint venture of conservation and climate protection facilitated by consumers and enacted by producers, emphasizing 'partnership' without questioning Northern and Southern choices that render climate action necessary in the first place. The analysis, however, questioned the 'partnership' meaning in terms of whether Southern agency was accurately represented and to what extent Southern voices were reflected in the initiative's communications. Another question was to what degree the emphasis on 'helping' shaped Southern realities on the ground in terms of what conduct was valuable and 'should be' in keeping with derivative value (Büscher 2010; Crush 1995). This case supports my argument that representations are at odds with underlying priorities. They make evident underlying power relations, but also, through the emphasis on philanthropy over necessity, entail problematic implications for Southern producers in terms of deprioritizing their interests and voices.

\section{Floral: dynamics, drivers and representations}

Floral is, on the world scale, a medium-sized chocolate company that prides itself on being 'different', advocating a commitment to quality, its family-owned tradition and caring beyond the bottom line. It certified parts of its range organic earlier than most mainstream companies, showing a wider engagement with environmental causes (Frankfurter Rundschau 2011). Equally, its European production facilities boast solar panels and a combined heat-and-power-plant, while receiving electricity from a renewable energy provider. In terms of cocoa production, the company explains its environmental goals as follows: "Cocoa is a key ingredient for our products, which we source from Third World countries. We therefore have a particular responsibility towards these countries. Of course, protecting tropical forests needs support from industrialized countries. We aim to make our contribution." (Floral n.d.b: para 6) Among producers and cooperatives, there has been an appreciation of Floral's premium prices and stability: 
We know that whatever [cocoa] we produce in high quality, we can always sell to Floral; they provide a good, stable market, unlike we see in [other crops]. ${ }^{9}$

We are quite happy with the services Floral offers. Like everyone else, we have had contacts with other buyers [with] lower quality requirements. But no-one can offer Floral's prices, because they process their cocoa themselves. ${ }^{10}$

Going beyond Floral's pre-existing commitments to organic cultivation and rainforest protection, the company's recent establishment of its own cocoa plantation in Nicaragua aims to offset carbon emissions while also providing biodiversity conservation benefits (Floral, n.d.b, c). Out of 2,000 hectares acquired, 1,300 ha are for cocoa cultivation under certified conditions, with the remaining land incorporated into the Mesoamerican biological corridor and dedicated to offsetting. ${ }^{11}$ The company's commitments in Nicaragua have evolved considerably over time, moving from a social-development approach via a focus on organic cultivation to its own plantation. ${ }^{12}$ These goals have transformed in response to fluctuations on world markets, with added urgency in the cocoa sector promoting a focus on commercial drivers such as productivity and safeguarding security of supply. The assumption is that a plantation under the company's control is more secure, although cooperations with smallholder growers and cooperatives continue. However, in an in-house cultivation venture, there is clearly even less opportunity for Southern stakeholders to contribute priorities than in collaborations with cooperatives and smallholders, exemplifying the same power asymmetries favoring the global North and private-sector stakeholders that recur throughout the sector.

In terms of the representations that Floral uses in sustainability documentation and online, they firstly emphasize their pioneering efforts dictated by their family-run tradition, and secondly local environmental and socio-economic benefits. A sustainability report explains:

Long before organic agriculture became a subject everyone is talking about, the company CEOs founded the project 'Macacao' in Nicaragua in 1990. The idea of the family business owners was as good as it was ambitious: they aimed to promote the production and marketing of sustainably grown cocoa, protect natural forests and offer local producers a secure livelihood. (Floral 2011: 6)

This passage confirms the recurring theme of Floral being different, emphasizing that the company was a pioneer in sustainability awareness and engagement-at-origin. Its stated aim "to do business in harmony with nature" (Floral 2013b: 18) also recurs here given its intention to "protect natural forests" and its commitment to organic agriculture. There is a clear link back to Muir's wilderness as well as Bryant and Goodman's positive connotations associated with 'nature', while again raising questions around what nature is promoted as desirable (Cronon 1996). There is little problematization of what nature is being commodified (Castree 2003) or if the company's global and local market relations foster inequities and nonviable consumption behaviors (Soper 1998). Equally, the characterization of a cooperative as a 'project' is interesting, confirming the need for external assistance - which was also identified for Our Chocolate. The report then goes on to highlight a 'quality' theme, emphasizing the benefits for consumers from buying this chocolate, as well as the support for multiple generations of cocoa farmers in Nicaragua. A personal testimony by a farmer emphasizing that three generations of his family are active in the 'Macacao'

\footnotetext{
${ }^{9}$ Interview \#80, cooperative representative, 12 February 2014.

${ }^{10}$ Field notes, representative of cooperative, 26 February 2014.

${ }^{11}$ Interviews \#54, \#95, \#96, private sector representatives, on 27 January 2014, 5 March 2014 and 5 March 2014 ; \#57 and \#66, civil society representatives, on 27 January 2014 and 30 January 2014.

12 Interviews \#93, private sector representative, on 4 March 2014; \#90, development representative, on 22 February 2014; \#80, cooperative representative, on 12 February 2014; \#34 and \#117, civil society, on 13 November 2013 and 24 March 2014.
} 
cooperative harks back to Bryant and Goodman's observation about stakeholders employing narrative testimonies to create links between producers in the global South and consumers in the North (2004: 357).

In particular, the company represents its shift to cultivating its own plantation as a logical continuation of its prior commitment as well as safeguarding production that lives up to its environmental and social expectations: "The goal is as clear as it is ambitious: ecologically and socially cultivated cocoa for Floral. ... buying land and starting one's own sustainable cocoa cultivation is the most effective way to exert maximum influence on ecological and social conditions in cocoa cultivation." (Floral, n.d.a: 1). This passage construes the shift towards in-house cultivation as a necessity. It is about improving ecological and social conditions of cocoa production, not responding to imminent cocoa shortages in the sector. Company representations also highlight its 'ambitious' goals, and the need for assisting producers. The 'helping' narrative confirms and reinforces the power asymmetry between company and cocoa communities, while cementing a very particular understanding of what nature is to be supported (Cronon 1996). This logic reinforces the company's belief that it is acting voluntarily rather than following business imperatives: that they wish to make these changes, producing and reproducing altruistic motivations. This representation equally neglects to engage with the destructive effects that capitalist markets tend to entail for nature and communities (Soper 1998) and have produced in bringing about the cocoa sector's current predicament, painting their engagement as coming out of goodness rather than necessity.

Focus group discussions with responsive consumers revealed a considerable spectrum of opinions on Floral and its efforts. Numerous participants viewed Floral positively given its reputation as an ethical employer with family-run values:

If I feel like chocolate, then ... I will buy Floral because I know there is a socially responsible company behind it, ... at least their employees in Germany are ok, and ... at least I am not supporting [a big corporation]. ${ }^{13}$

I think it's a good thing that a company like Floral gets involved like that ... if I see the [organic] seal, on the more expensive one, then all the more. ... because I know that I'm not just getting good quality, but I'm also ... maybe not socially responsible, but I'm doing something good ${ }^{14}$

Interestingly, the representations Floral uses to characterize its engagement hardly changed despite the paradigmatic shift to in-house production, accentuating the tension between underlying commercial drivers and the socio-ecological motivations cited in public-facing communication:

For us as a comparatively small medium-sized company, acquiring land and becoming involved in sustainable cocoa cultivation is the most effective way to exert maximum influence on the ecological and social conditions of cocoa cultivation ... Consistently auditing cultivation and working conditions in mostly smallholder cultivation structures worldwide is not viable for us in terms of human and financial resources. However, fair working conditions and protecting the environment are key values in our 100-year company philosophy. Therefore we have chosen to take this step, which is admittedly unusual for a chocolate producer. After all, we stand for a 'different' chocolate in various ways. (Company head cited in press release; Floral 2013a: 1)

The self-characterization as a "comparatively small medium-sized company" recalls the concentrated successive oligopolies dominating the chocolate sector, which dwarf Floral. The concession that they have neither sufficient financial nor human resources to monitor all smallholder production is a positive departure

\footnotetext{
${ }^{13}$ Focus group discussion on 5 December 2013, Participant $1 \mathrm{f}$.

${ }^{14}$ Focus group discussion on 23 April 2014, Participant 2j.
} 
from most large-scale cocoa stakeholders' communications, who often represent certification and 'sustainability' awareness as a panacea. Again, the notion of being 'different' resurfaces, reiterating that their socio-ecological awareness is due to value-driven considerations rather than commercial pressures. But this representation neglects to acknowledge the radically different situation in the cocoa sector, its shortage projections and its commercial imperative.

There is a strong suggestion that Floral's representations of its work are to harness positive associations from altruistically minded consumers. Implicitly, the emphasis on 'helping' not only constructs a need for outside assistance rather than equal trading partnerships (Crush 1995), but also reinforces existing power asymmetries. Without an acknowledgement that power constellations favoring the global North and the private sector contributed to the socioecological problems causing concern, there is no need to alter these lop-sided structures and to address inequities. This not only preserves altruistic representations and their benefit for the company, but distracts from the ways that cocoa stakeholders' detrimental socioenvironmental behaviors have contributed to the cocoa sector's current predicament. As with Our Chocolate, incongruent, overly favorable representations emphasizing partnership and 'helping' are perpetuating the issues that sustainability initiatives purport to address, prolonging inequalities which favor the global North and the private sector. What is more, these representations produce and reproduce power asymmetries that the sector needs to remedy in order to move towards genuine 'sustainability.'

\section{Representing cocoa sustainability: the (re)production of meaning}

This article has illustrated a considerable discrepancy between cocoa stakeholders' representations and drivers relating to sustainability, emphasizing the need to unpack complex relationships as a way to analyze underlying power relations. The analysis of the two cases demonstrated that the representations utilized emphasize socio-economic and environmental facets, not the commercial supply-security aspects which are increasingly driving the sector. Commercial aspects are only mentioned insofar as they benefit consumers directly, such as high-quality cocoa being transformed into flavorful chocolate. In keeping with Goodman's arguments about the moral economy (2004), what renders the chocolate bars in question 'good' are altruistic elements, requiring representations that emphasize philanthropy over self-serving necessity. In terms of Raynolds's (2009) mission-driven and market-driven drivers, companies are representing commercial priorities as altruistically minded, thereby neglecting to forefront the cocoa sector's very real shortcomings and inequalities which have contributed to the current predicament.

These unchanged asymmetries, including the miniscule share of Southern growers in chocolate retail revenue compared with the added value retained by the global North, stand in the way of genuine cocoa sustainability. While the observed discrepancy between deployed representations and underlying drivers may not be surprising in itself, thinking through its implications is essential. The power to project narratives is indicative of the cocoa sector's power dynamics, which remain unchanged despite public-facing representations emphasizing 'sustainability' and 'partnership.' Genuine cocoa sustainability is difficult to define given different stakeholders' diverging understandings (Adams 2009) as well as sustainable development's oxymoronic tendencies (Redclift 2005), requiring negotiation between stakeholders in each initiative. Undoubtedly, however, it involves redressing imbalances and moving away from short-termist thinking towards incorporating Southern producers' expert voices in favor of long-term, socioenvironmental goals. Both case studies demonstrated some progress in terms of improving producer incomes and advancing some environmental awareness, thereby constituting more positive examples than some and justifying some measure of their emphasis on being value-driven and 'different.' Nevertheless, the many paradoxes uncovered are emblematic of the progress which the sector has yet to make in terms of taking Southern voices seriously, and going beyond narratives of partnership towards incorporating socioenvironmental, long-term priorities into sustainability initiatives. This shows how far away the sector currently is from producing an 'alternative to the alternative' (Goodman 2010). From a political ecology perspective, it reinforces the need for further research on how assumed 'sustainability' redresses, claims to remedy, or reproduces underlying power asymmetries between producers and consumers. This requires an unpacking of projects' representations, based on their drivers and their consequences for intended 
beneficiaries. This speaks to broader debates on the relationship between sustainability and justice. There is no automatic link between them, and a need for further research across the nexus of development studies, political ecology and consumption studies.

Within the spectrum of altruistic representations deployed, environmental benefits tended to win out over livelihood benefits for cocoa producers. This has a strong link back to the positive associations with 'nature' and 'rainforest' narratives that Bryant and Goodman identify as escapism from unsustainable lifestyles (2004). Failing to challenge non-viable behaviors that render escapism necessary in the first place is a common cognitive dissonance extending far beyond cocoa sustainability. It raises fundamental questions around what notions of nature and communities are being hailed (Cronon 1996) or commodified (Castree 2003), drawing very narrow lines around what kind of conduct, and solutions, are acceptable. It also illustrates the power of 'sustainability' representations which forefront perceptions of 'partnership' and 'equality' irrespective of actual outcomes, while distracting from the way that initiatives perpetuate detrimental socio-environmental behaviors through unchanged capitalist relations (Carrier 2010; O'Riordan 2004). Again, flawed representations are reproducing the shortcoming they purport to bridge.

The case studies also showed that socio-economic improvements for producers primarily served as a means to enact rainforest protection or carbon sequestration. Firstly, within cocoa sustainability, there is a certain novelty aspect to environmental protection that the well-established idea of improving producer livelihoods cannot claim. A second and related point concerns Silverstone's 'proper distance', i.e. the idea that audiences "need to be close but not too close, distant but not too distant" to the subjects of representations in order to care and connect to them (2007: 172). The case studies placed an emphasis on constructing proper distance at the environmental rather than the socio-economic level. I argue that a connection appeared easier to strike on matters of ecology than livelihood. Socio-economically, chocolate consumers, i.e. the primary Northern audience of representations on cocoa sustainability initiatives, are 'worlds apart' from the Southern cocoa producers that the representations report upon ${ }^{15}$ in terms of the livelihoods they pursue, the buildings they inhabit, or the priorities that motivate their engagement. In fact, as especially Our Chocolate's public presentation and interpretation by project staff inadvertently showed, this significant discrepancy in terms of life realities between consumers and producers is a key prerequisite for a 'helping' narrative to be credible.

Conversely, a sense of community between these - in themselves highly heterogeneous - groups is easier to establish narratively in the environmental sphere. Firstly, the common enemy between producers and consumers is less morally charged. In the socio-economic sphere, the inequities of the global capitalist system are perpetually constructed by human choice and particularly the actions of the global North towards the global South. In the cases of rainforest destruction, species extinction and climate change, the links to human action and the global North are no less present, but arguably less apparent: the phenomena are often represented and perceived as rather amorphous transformations possessing no clear origin and posing a threat to us all, constituting a unifying theme. The two initiatives constructed a sense of joint opportunity to challenge climate change and promote further conservation through their representations, with the focus being predominantly on positive notions such as limiting deforestation and conserving biodiversity rather than a guilt-laden idea of rectifying Northern-induced human suffering. In resurrecting the rainforest narratives which Bryant and Goodman (2004) identified as sales-friendly, both initiatives construct unifying aspirations to save rainforests and aid nature together e.g. by pointing out that cocoa producers wish to protect their biodiverse environments with Northern funds. However, these common goals gloss over, and arguably perpetuate, existing power asymmetries between producers and consumers, and by extension global North and South, prioritizing environmental benefits over socio-economic advancements for Southern stakeholders.

Finally, representations reinforcing 'helping' narratives raise a number of broader issues. Numerous stakeholders as well as focus group participants expressed desires to 'help' producers by paying extra. Firstly, this means that consumers will expect representations regarding sustainability initiatives to conform to and reinforce this 'helping' narrative: this prescribes what other initiatives should forefront and implement

\footnotetext{
${ }^{15}$ Interview \#117, civil society representative, on 24 March 2014.
} 
in terms of what kind of nature and community has value (Büscher 2010). These normative, albeit often subconscious, expectations also prescribe the norms for the behaviors in the global South worthy of 'helping.' Secondly, representations reinforce the partiality of certification initiatives that help the few, rather than challenge the fundamental injustices inherent in capitalist relations (Soper 1998). In fact, for some, placating one's bad conscience through compartmentalized support for the few will work to uphold power asymmetries and structurally unjust relations everywhere else. Again, there is a need to investigate to what extent this finding holds true across other debates, especially on sustainability standards.

Out of these considerations on 'helping', a broader question emerges regarding the 'partnership' story recurring in a multitude of projects spanning Raynolds's North-South divide (2002). Most fundamentally, representations forefronting 'helping' solidify in consumers, producers and Northern stakeholders alike, a sense that helping is the right mode of operation, without ever questioning how a transaction in which a commodity changes hands could ever be depicted as a unilateral, altruistic act of charity. This constitutes a fundamental deficiency in terms of justice, as this dynamic serves to cement existing images of people of color in the global South as in need of assistance, contravening the narratives of 'partnership' recurring in both case studies. While aspects such as the mutual delegation visits in the municipalities' initiative parallel actual, equal partnership, most connections established in the initiatives, following Silverstone (2007), are merely screen-deep: they prompt purchases, but facilitate engagement only within the confines set by the boundaries of Northern representations, irrespective of claims of partnership. This would thus fall short of wealthy Northerners taking their duties towards distant strangers seriously (Corbridge 1993): instead, 'helping' representations projected by powerful stakeholders constitute and delimit consumers' expectations, while prescribing and shrinking stakeholders' options as well as dictating and restricting producers' realities. While none of these observations are new, a point for further research is to what extent 'sustainability' initiatives, i.e. activities commonly assumed to entail positive outcomes, are perpetuating and cementing unequal relations, reproducing injustices which they purport to bridge.

In sum, the argument that representations produce and reproduce pre-existing power asymmetries was confirmed in the two cases. While recent societal discourse has prompted more stakeholders in cocoa to engage with 'sustainability', the growing spectrum of stakeholders exacerbates tensions between and within socio-economic, environmental and commercial 'sustainability' drivers, but also between drivers and representations. Power asymmetries are unchanged, even in recent sustainability initiatives using assumptions and narratives of 'partnership.' In fact, representations highlighting altruism rather than business imperatives, which dress up market-driven as mission-driven imperatives, suggest there is no need to change the sector's underlying inequities and thus risk aggravating them. Tweaking business as usual is painted as sufficient, with the expectation that positive associations with altruistic motives will endear stakeholders to responsive constituencies. This also pulls into question to what extent stakeholders are engaging meaningfully with the power asymmetries and poor practices causing shortage fears in the first place, including environmentally degrading productivity maximization or socio-economically damaging low prices. Acknowledging existing socio-environmental inequalities would risk stripping Northern stakeholders of the reputational and ideational benefits they can derive from their 'sustainability' efforts. However, neglecting to recognize inequalities equally jeopardizes finding adequate answers to the systemic problems threatening the sector, thereby failing to build consumers' acceptance for sweeping changes as well as the equal alliances necessary to challenge existing power asymmetries and effect systemic change.

\section{Conclusion}

This article has analyzed representations that stakeholders have deployed within cocoa sustainability initiatives, linking them with underlying priorities as well as to the power dynamics governing these exchanges. Through a conceptual review of literatures on representations and ethical consumption, it constructed a framework to analyze representations and their links to underlying priorities and power dynamics in two specific case studies investigated through in-depth fieldwork. These cocoa sustainability initiatives with environmental foci allowed diverse insights into how meanings of 'helping' and philanthropy are deployed in public-facing representations, emphasizing the relevance of these narratives in broader 
sustainability discourse and the need for further research. The links connecting public-facing representations, underlying priorities, and power relations illuminate how stakeholders project a corporate image, and with what priorities and meanings.

Constantly stressing altruism and partnership conceals commercial pressures stemming from the cocoa sector's projections of future production shortages. While this is unsurprising to political ecologists, it has problematic implications for supposedly 'good' sustainability initiatives building 'partnerships.' This public-facing communication not only tones down addressing systemic issues, but also reproduces existing power asymmetries favoring the global North and the private sector. This dynamic works to produce and reproduce the systemic inequalities and issues that such initiatives purport to bridge. Consequently, the article has underlined the need to unpack meanings and their implications as a precursor to advancing towards genuine sustainability by taking seriously cocoa growers' socio-environmental priorities.

\section{References}

Adams, W.M. 2009. Green development: environment and sustainability in the Third World. 3rd edition. London: Routledge.

Agenda21. 2015. Eine Partnerschaft mit schmackhaften Früchten - Schokolade als Maßnahme des Klimaschutzes [A partnership with tasty fruits - chocolate as a climate-protection measure]. [accessed 13/01/2015]. http://www.agenda21.de/

Alexander, W.L. 2018. Testing the water, challenging the narrative of sustainable development: student volunteer research promoting public health in rural Panama in the shadow of an "eco-playground." Journal of Political Ecology 25: 64-79.

Barrientos, S., K. Asenso-Okyere, S. Asuming-Brempong, D. Sarpong, N. Anyidoho, R. Kaplinsky and J. Leavy. 2008. Mapping sustainable production in Ghanaian cocoa. Report to Cadbury. [accessed 11/02/2015].

http://www.bwpi.manchester.ac.uk/medialibrary/research/ResearchProgrammes/businessfordevelop ment/mappping_sustainable_production_in_ghanaian_cocoa.pdf

Barrientos, S. 2002. Mapping codes through the value chain: from researcher to detective. In R. Jenkins, R. Pearson and G. Seyfang (eds.) Corporate responsibility and labour rights: codes of conduct in the global economy. London: Earthscan. Pp. 61-76.

Barrientos, S. 2014. Gendered global production networks: analysis of cocoa-chocolate sourcing. Regional Studies 48(5): 791-803.

Baudrillard, J. 1976. Toward a critique of the political economy of the sign. SubStance 5(15): 111-116. Translated by C.R. Lovitt and D. Klopsch.

Baudrillard, J. 1988. The system of objects. In J. Baudrillard (ed.) Selected writings. Cambridge: Polity Press. Pp. 10-28.

Baudrillard, J. 1998. The consumer society - myths and structures. London: Sage.

Baudrillard, J. 2001. Selected writings. 2nd edition. Oxford: Blackwell.

Bendell, J. 2005. The AccountAbility of Corporate Social Responsibility. Development in Practice 15 (3/4): 362-374.

Benjamin, W. 1989. On the program of the coming philosophy. In G. Smith (ed.) Benjamin: philosophy, aesthetics, history. Chicago: University of Chicago Press. Pp. 1-12.

Bitzer, V., P. Glasbergen and P. Leroy. 2012. Partnerships of a feather flock together? An analysis of the emergence of networks of partnerships in the global cocoa sector. Global Networks 12(3): 355-374.

Bixler, R.P. 2013. The political ecology of local environmental narratives: power, knowledge, and mountain caribou conservation. Journal of Political Ecology 20: 273-285.

Blowfield, M. and C.S. Dolan. 2008. Stewards of virtue? the ethical dilemma of CSR in African agriculture. Development and Change 39(1): 1-23. 
Bryant, R.L. and M.K. Goodman. 2004. Consuming narratives: the political ecology of 'alternative' consumption. Transactions of the Institute of British Geographers 29(3): 344-366.

Büscher, B. 2010. Derivative nature: interrogating the value of conservation in 'Boundless Southern Africa'. Third World Quarterly 31(2): 259-276.

Caplan, P. 2016. Sustainable development? Controversies over prawn farming on Mafia Island, Tanzania. Conservation and Society 14(4): 330-344.

Cargill. 2015. Cargill completes acquisition of ADM's global chocolate business, deepening service offering to its customers. [accessed 03/10/2015]. http://www.cargill.com/news/releases/2015/NA31877259.jsp

Carrier, J. 2010. Protecting the environment the natural way: ethical consumption and commodity fetishism. Antipode 42 (3), pp. 672-689.

Castree, N. 2003. Commodifying what nature? Progress in Human Geography 27(3): 273-297.

CIAT - Centro Internacional de Agricultura Tropical. 2011. Predicting the impact of climate change on the cocoa-growing regions in Ghana and Côte d'Ivoire. Report prepared by P. Läderach, A. Eitzinger, A. Martínez and N. Castro. Available at: http://www.eenews.net/assets/2011/10/03/document_cw_01.pdf [accessed 23/01/2013].

Climate Alliance. 2014a. Home. [accessed 22/04/2014]. http://www.klimabuendnis.org/

Climate Alliance. 2014b. Details on Verheiden. [accessed 22/04/2014]. http://www.klimabuendnis.org/

Corbridge, S. 1993. Marxisms, modernities, and moralities: development praxis and the claims of distant strangers. Environment and Planning D: Society and Space 11(4): 449-472.

Corporación Tilón. 2014. Presentación - Corporación Tilón [Presentation - Corporación Tilón; PPT]. Given on 7 July 2014.

Cronon, W. 1996. The trouble with wilderness: or, getting back to the wrong nature. Environmental History 1(1): 7-28.

Crush, J. 1995. Imagining development. In J. Crush (ed.) Power of development. London: Routledge. Pp. 126.

Debord, G. 1967. The society of the spectacle. Trans. 1970. Detroit: Black \& Red.

Elgert, L. 2012. Certified discourse? The politics of developing soy certification standards. Geoforum 43(2): 295-304.

Escobar, A. 1995. Imagining a post-development era. In: J. Crush (ed.) Power of development. London: Routledge. Pp. 211-227.

Floral. 2011. Nachhaltigkeitsbericht [Sustainability Report]. [accessed 24/07/12].

Floral. 2013a. Floral und nachhaltiger Kakaoanbau. Press release [Floral and sustainable cocoa cultivation] [accessed 27/11/2013].

Floral. 2013b. Leitbild, July 2013 [Company philosophy; PDF]. [accessed 20/01/2015].

Floral. n.d.a. Produktverantwortung [Product responsibility; PDF]. [accessed 15/01/2015].

Floral. n.d.b. Unser Engagement [Our commitment; HTML]. [accessed 15/10/2012].

Floral. n.d.c. Ökologie [Ecology; HTML]. [accessed 15/10/2012].

Fountain, A.C. and F. Hütz-Adams. 2015. Cocoa Barometer 2015. [accessed 03/10/2015]. http://www.cocoabarometer.org/Download_files/Cocoa\%20Barometer\%202015\%20Print\%20Friend ly\%20Version.pdf

Franzen, M. and M. Borgerhoff Mulder. 2007. Ecological, economic and social perspectives on cocoa production worldwide. Biodiversity Conservation 16: 3835-3849.

Glin, L.C., P. Oosterveer and A.P.J. Mol. 2015. Governing the organic cocoa network from Ghana: towards hybrid governance arrangements? Journal of Agrarian Change 15(1): 43-64.

Goodman, M.K. 2004. Reading fair trade: political ecological imaginary and the moral economy of fair trade foods. Political Geography 23: 891-915. 
Goodman, M.K. 2010. The mirror of consumption: celebritization, developmental consumption and the shifting cultural politics of fair trade. Geoforum 41: 104-116.

Hainmueller, J., M.J. Hiscox and M. Tampe. 2011. Sustainable development for cocoa farmers in Ghana. Baseline survey: preliminary report. [accessed 12/08/2012]. http://www.responsibleagroinvestment.org/rai/sites/responsibleagroinvestment.org/files/Ghana\%20C ocoa\%20Baseline\%20Report Jan\%202011.pdf

Hall, S. 1997a. Introduction. In S. Hall (ed.) Representation: cultural representations and signifying practices. Milton Keynes: The Open University. Pp. 1-12.

Hall, S. 1997b. The work of representation. In S. Hall (ed.) Representation: cultural representations and signifying practices. Milton Keynes: Open University. Pp. 13-74.

Henderson J, P. Dicken, M. Hess, N. Coe and H.W. Yeung. 2002. Global production networks and the analysis of economic development. Review of International Political Economy 9(3): 436-464.

Hess, M. 2004. 'Spatial' relationships? Towards a reconceptualization of embeddedness. Progress in Human Geography 28(2): 165-186.

Henson, S. and J. Humphrey. 2008. Understanding the complexities of private standards in global agri-food chains. [accessed 05/08/2012]. http://www.ids.ac.uk/files/dmfile/HensonHumphreyLeuvenOct08.pdf

Hilson, G. 2014. 'Constructing' ethical mineral supply chains in Sub-Saharan Africa: the case of Malawian Fair Trade Rubies'. Development and Change 45(1): 53-78.

Hoelle, J. 2017. Jungle beef: consumption, production and destruction, and the development process in the Brazilian Amazon. Journal of Political Ecology 24, pp. 743-762.

Hughes, A. 2001. Global Commodity networks, ethical trade and governmentality: organizing business responsibility in the Kenyan cut flower industry. Transactions of the Institute of British Geographers 26(4): 390-406.

Hütz-Adams, F. and A.C. Fountain. 2012. Cocoa barometer 2012. [accessed 23/01/2013]. http://www.suedwind-institut.de/fileadmin/fuerSuedwind/Publikationen/2012/201244_Cocoa_Barometer_2012_Druckfreundlich.pdf.

Kalamandeen, M. and L. Gillson. 2007. Demything 'wilderness': implications for protected area designation and management. Biodiversity and Conservation 16: 165-182.

Klooster, D. 2006. Environmental certification of forests in Mexico: the political ecology of a nongovernmental market intervention. Annals of the Association of American Geographers 96(3): 541-565.

Krauss, J. 2017. What is cocoa sustainability? Mapping stakeholders' socio-economic, environmental, and commercial constellations of priorities. Enterprise Development and Microfinance 28(3): 228-250.

Laws, S. 2003. Research for development: a practical guide. With C. Harper and R. Marcus. London: Sage.

Lewis, D., D. Rodgers and M. Woolcock. 2008. The fiction of development: literary representation as a source of authoritative knowledge. Journal of Development Studies 44 (2): 198-216.

Lewis, D., D. Rodgers and M. Woolcock. 2013. The projection of development: cinematic representation as a(nother) source of authoritative knowledge? Journal of Development Studies 49(3): 383-397. Working paper

Lewis D., D. Rodgers and M. Woolcock. 2014a. The fiction of development: literary representation as a source of authoritative knowledge. In D. Lewis, D. Rodgers and M. Woolcock (eds.) Popular representations of development: insights from novels, films, television and social media. London: Routledge. Pp. 17-37.

Lewis D., D. Rodgers and M. Woolcock. 2014b. Introduction: popular representations of development. In D. Lewis, D. Rodgers and M. Woolcock (eds.) Popular representations of development: insights from novels, films, television and social media. Abingdon: Routledge. Pp. 3-16.

Lukes, S. 2005. Power - a radical view. $2^{\text {nd }}$ edition. Basingstoke: Palgrave Macmillan. 
Mason, C. and B. Doherty. 2016. A Fair Trade-off? Paradoxes in the governance of Fair-trade social enterprises. Journal of Business Ethics 136(3): 451-469.

Matissek, R., J. Reinecke, O. von Hagen and S. Manning. 2012. Sustainability in the Cocoa sector - review, challenges and approaches. Moderne Ernährung Heute, Official Journal of the Food Chemistry Institute of the Association of the German Confectionery Industry. February: 1-27.

Marin-Burgos, V., J. Clancy and J. Lovett. 2015. Contesting legitimacy of voluntary sustainability certification schemes: valuation languages and power asymmetries in the Roundtable on Sustainable Palm Oil in Colombia. Ecological Economics 117: 303-313.

McAfee, K. 1999. Selling nature to save it? Biodiversity and the rise of green developmentalism. Environment and Planning D: Society and Space 17(2): 133-154.

Nieburg, O. 2013. Cargill closes in on ADM Cocoa - reports. [accessed 08/03/2014]. http://www.confectionerynews.com/Commodities/Cargill-closes-in-on-ADM-Cocoa-reports

Nieburg, O. 2017. Chocolate makers must up cocoa prices to avert poverty. [accessed 06/05/2017]. http://www.confectionerynews.com/Commodities/Chocolate-makers-must-up-cocoa-prices-to-avertpoverty-NGOs

Ofori-Boateng, K. and B. Insah. 2014. The impact of climate change on cocoa production in West Africa. International Journal of Climate Change Strategies and Management 6(3): 296-314.

O'Laughlin, B. 2007. Interpreting institutional discourses. In A. Thomas and G. Mohan (eds.) Research skills for policy and development: how to find out fast. London: The Open University. Pp. 135-156.

O'Shaughnessy, M. and J. Stadler. 2005. Media and society: an introduction. $3^{\text {rd }}$ edition. Oxford: Oxford University Press.

O'Riordan, T. 2004. Environmental science, sustainability and politics. Transactions of the Institute of British Geographers 29(2): 234-247.

Oya, C., F. Schaefer, D. Skalidou, C. McCosker and L. Langer. 2017. Effects of certification schemes for agricultural production on socio-economic outcomes in low- and middle-income countries: a systematic review. 3ie Systematic Review 34. London: International Initiative for Impact Evaluation (3ie).

Otterbach - Municipality of Otterbach. 2014. Chocolate wrapper [as of July 2014].

Raynolds, L.T. 2002. Consumer/producer links in Fair Trade coffee networks. Sociologia Ruralis 42: 404424.

Raynolds, L.T. 2009. Mainstreaming Fair Trade coffee: from partnership to traceability. World Development 37 (6): 1083-1093.

Redclift, M.J. 2005. Sustainable development (1987-2005): an oxymoron comes of age. Sustainable Development 13: 212-227. doi:10.1002/sd.281

Silverstone, R. 2007. Media and morality: on the rise of the mediapolis. Cambridge: Polity.

Smith, S. 2008. For love or money? Fairtrade business models in the UK supermarket sector. Paper prepared for the 3rd Fair Trade International Symposium, 14-16 May 2008, Montpellier, France. [accessed 07/01/12] http://www.ids.ac.uk/files/dmfile/SmithFTIS2008supermarketFT.pdf.

Soper, K. 1998. Representing nature. Capitalism, Nature, Socialism 9 (4): 61-65.

Tallontire, A. and V. Nelson. 2013. Fair trade narratives and political dynamics. Social Enterprise Journal 9(19): 28-52.

Tampe, M. 2016. Leveraging the vertical: the contested dynamics of sustainability standards and labour in global production networks. British Journal of Industrial Relations 56(1): 43-74.

Tharoor, S. 1999. Are human rights universal? World Policy Journal 16(4): 1-6.

Thornton, P. 2010. Cocoa production 2020. [accessed 15/06/2012].

http://www.worldcocoafoundation.org/who-we-are/partnership-meetings/documents/PThorntonArmajaro.pdf 
Tilón - Rural Association of Tilón. 2014. Apoyo a las iniciatives de emprendimientos productivas sostenibles de los campesinos e indígenas en el municipio de Tilón, Colombia [Support to productive, sustainable, income-generating initiatives for campesinos and indigenous people in the Tilón municipality; DOC]. Tilón: Campesinos de Tilón.

Weber, M. 2005 [1922]. Wirtschaft und gesellschaft: grundriss der verstehenden soziologie [Economy and Society. Blueprint of understanding sociology]. 5th edition. Tübingen: Mohr Siebeck.

Wilkinson, J. 2007. Fair Trade: dynamic and dilemmas of a market-oriented global social movement. Journal of Consumer Policy 30(3): 219-239.

Wilkinson, J. and L. Mascarenhas. 2007. The making of the Fair Trade movement in the South: the Brazilian case. In L. Raynolds, D. Murray and J. Wilkinson (eds.). Southern social movements and Fair Trade. London: Routledge. Pp. 125-157.

Zadek, S. 1998. Balancing performance, ethics, and accountability. Journal of Business Ethics 17(13): 1421-1441. 